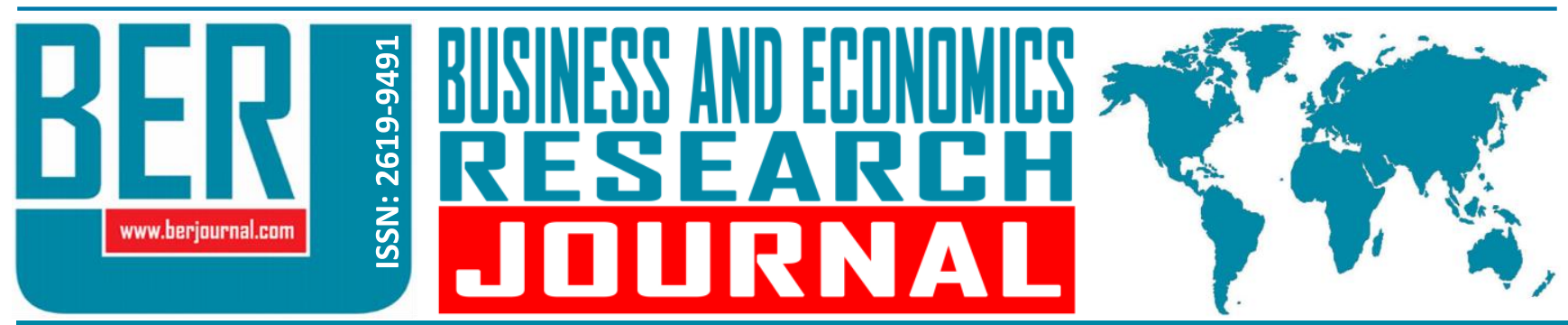

Business and Economics Research Journal Vol. 10, No. 5, 2019, pp. 1039-1049 doi: 10.20409/berj.2019.220

\title{
Interaction of Monetary and Fiscal Policies in Turkey: A Dynamic Time Series Data Analysis ${ }^{1}$
}

\begin{abstract}
Asli Guler
Abstract: Monetary and fiscal policies are designed and implemented by different government agencies, each with its own objectives, resources, constraints, and incentives. The actions of monetary authority may affect the fiscal authority's public debt management and fiscal deficit. On the other side, the fiscal authority's action also may affect the stance of monetary policy and its results. This paper aims to find the level of fiscal or monetary dominance by evaluating the interaction of monetary and fiscal policies in Turkey for relevant period. For this purpose, it was examined the relationship between inflation rate, monetary policy interest rate, fiscal deficit, public debt in Turkey for 2000 to 2018 by using VAR and ARDL model. According to the results obtained from VAR analysis monetary variables significantly affect fiscal variables. However, there is no evidence of fiscal dominancy on monetary policy. The evidence acquired via ARDL bound test supports these findings. Hereunder, it can be concluded that monetary policy is dominating fiscal policy in the relevant period.
\end{abstract}

Keywords: Unpleasant Monetarist Arithmetic, Monetary dominancy, Fiscal Dominancy, Policy Interaction

JEL: E37, E58, E62

Received : 27 May 2019

Revised : 01 August 2019

Accepted : 09 September 2019

Type : Research

\section{Introduction}

One of the pillars of macroeconomic policy is monetary policy and the other is fiscal policy. Monetary and fiscal policies are designed and implemented by different government agencies, each with its own objectives, resources, constraints, and incentives. Fiscal and monetary policies have a profound impact on different sides of the economy. The final effect of the measures taken in any of these areas will inevitably depend on how the policies in each area are affected by others (Hanif \& Arby, 2003: 1; Ekpo \& Omoruyi, 2013: 7). An unstable policy stance in one side forces the other side to be unstable and causes unsustainable policies on both sides in the long term. Policymakers and economists believe that almost all countries with uncoordinated monetary and fiscal policies are suffering from fiscal deficits and high real interest rates, inflation, and poor level of private investment and growth. Therefore it is essential to ensure close coordination between decision-makers in the areas of monetary and fiscal policies. (Nordhaus, 1994: 139; Laurens \& Piedra, 1998: 5). For example, consider the impact of a tax reduction financed by the new bond issue on consumer spending. Today, such a tax cut requires a combination of the following policy arrangements by expanding current and future budget deficits (Blinder, 1982: 11):

1. Rises in next period taxes,

2. Increases budgetary savings in the future, 
3. Monetary expansion in the future,

4. Increase in the future numbers of the interest-bearing national debt.

If the current decisions made by individuals and firms are affected by their future expectations, each of these alternatives may have a different result for the response to the tax cut today. For example, if people believe that a tax reduction funded by bonds decreases existing taxes and increases next period taxes to pay interest on bonds, consumption may continue existing level without affected. Actually, this argument belongs to Barro (1974). alternatively, people may expect monetary expansion eventually. Thus, emerging inflationary expectations may affect existing decisions in a manner that are not reflected by standard behavioral functions. This is essentially a point that Sargent \& Wallace (1981: 2) put forward when they claim that tight money can be inflationary.

According to "unpleasant monetarist arithmetic" published by Thomas Sargent and Neil Wallace at 1981, if the public debt ratio is a high, and fiscal policy does not show any interest in decreasing public debt, the real interest rate would be higher than real GDP growth rate. In this situation, it is not possible for the central bank to maintain a tight monetary policy to fight inflation. Initially, even if the central bank maintains a tight monetary policy, it will eventually have to turn on the taps of the money. In short, if fiscal policy is too loose, an independent monetary policy from fiscal policy is not possible.

This clearly means that when fiscal policy is indisciplined implementing a disciplined monetary policy becomes extremely difficult. The lack of credibility resulting from the long-term inconsistency would impair the effectiveness of the monetary policy. Especially if government debt reaches an extremely high level, efforts to take fiscal policies under the control may be useless. In these conditions, the mentioned difficulty in terms of monetary policy may turn into impossibility (Özatay, 2015: 341; Lambertini \& Rovelli, 2002: 2).

Weak interaction of monetary and fiscal policies emerges two concepts such as fiscal and monetary dominance. Fiscal dominance refers to the situation where fiscal policy is active and monetary policy is passive. In an economy with fiscal dominance, there is fiscal indiscipline. That is, the public debt is an unsustainable level and seniorage incomes are used to finance chronic budget deficits. Monetary dominance refers to the situation where monetary policy is lead and disciplined and fiscal policy is also disciplined. In order to prevent the need for seniorage revenues, public debt is kept at a sustainable level and budget surplus is tried to be given (Sargent \& Wallace, 1981: 1-2).

The independence of the central bank can be expected to improve economic performance by causing inflation to fall (Alesina \& Summers, 1993:152). However, unpleasant monetarist arithmetic suggests that if the country has both a debt stock of the past and the government persists not to give a budget surplus, the seniorage revenues will have to be increased. This means that the monetary authority will ultimately have to lend money to the treasury under conditions that lead to the unpleasant monetarist arithmetic. In fine, if the public debt is high in a country and no effort is made to ensure fiscal discipline, the continuity of central bank independence is not possible. Similar to Sargent \& Wallace (1981), Woodford (1995) remarked in his "Fiscal Theory of the Price Level" that the governmentís approach to fiscal deficit and financing method of this deficit can damage the central bank's capability to reach price stability, despite its legal independence. If the central bank is given independence to achieve price stability, then the government must ensure fiscal discipline to assure for any path the price level might take (Canzoneri, Cumby \& Diba, 2002: 356-357).

Aim of the paper is determining which of the monetary and fiscal policies is dominant in Turkey for 2000-2018. For this purpose, the effects of fiscal shocks and monetary shocks on each other, and the dynamics of short and long term relations between variables were analyzed by vector autoregression (VAR) and ARDL bound testing. In the following part of the study, the empirical literature is presented, then the econometric method is explained and the results of the analysis are shared. In the conclusion part, the findings obtained from the study were summarized and evaluations were made. 


\section{Review of Literature}

The literature on the monetary effects of fiscal discipline based on Sargent \& Wallace (1981) emphasizes that the monetary policy and price levels are no longer independent of fiscal policy if the fiscal deficit of the government is preestablished and unsustainable. This scenario, called "Unpleasant monetarist arithmetic" by Sargent \& Wallace, has been absolutely effective in motivating the subsequent studies evidenced that fiscal discipline is a prerequisite for monetary stability. In the case of huge debt stock, there are two options to be used in order to reduce this stock: either to give a budget surplus or increase the seniorage revenue by issuing money. If one cannot create sufficient surpluses, the other has to generate a surplus. If the fiscal deficits persist and the increase in the amount of money is low at the beginning, the debt stock grows. As a result, the Central Bank's unpleasant monetarist arithmetic comes to the face.

Following Sargent \& Wallace, Woodford (1995) pointed out a similar relationship between price stability and fiscal discipline in his "Fiscal Theory of the Price Level". In his theory, Woodford challenged the conventional views about requirements to reach a certain price level and remarked the role of government's fiscal policy in price level determination. The theory also argues that the central bank's independence is not sufficient to eliminate the inflationary consequences of fiscal policy. In other words, in an economy where there are a public deficit and debt stock is rising; price stability may not be achieved even in the presence of an independent and rigid central bank, and inflation may rise.

Canzoneri, Cumby \& Diba (2002) investigated the reaction of inflation and interest rate to fiscal shocks in America for the period 1984 to 2002 using structural Var method. They found a strong and statistically significant correlation between fiscal deficits and intermediate-term and long-term interest rates. According to structural VAR results, positive spending shocks lead to increases in interest rates. This suggests that a positive spending shock ought to lead to an increase in the federal funds rate. It is also found that inflation rises temporarily in response to a spending shock.

Aktaş, Kaya \& Özlale (2010) analyzed the implications of a tight monetary policy on major macroeconomic variables using impulse response functions for two sub-periods: July 2001 represents a period without fiscal discipline, and September 2003 represents a period with fiscal discipline. According to acquired results for the period of the fiscal indiscipline, an increase of policy rate causes an increase in the cost of debt service, and in the debt level. Thereafter this increase of the debt stock stimulates the risk premium inducing the central bank to raise the policy rate. On the other hand, the increase of the monetary policy rate in September 2003, as in the previous case, causes the treasury bill rate to increase. However, this increase causes a limited increase in the debt stock and the risk premium, that does not lead concerns about its sustainability.

Ahmad, Sheikh \& Tariq (2012) analyzed the influence of domestic debt on inflation using time series of Pakistan from 1972 to 2009. It is found that domestic debt and domestic debt service has an additive effect on the price level in Pakistan. It is also found that one of the major reasons for the budget deficit in Pakistan is interest rate i.e. the cost of domestic borrowing or debt servicing. These findings indicate that the government has to finance the budget deficit from the central bank resources, which leads to inflation. According to the study fiscal policy is dominating monetary policy in Pakistan.

Daly (2015) investigates the mutual relationships amongst fiscal deficit, public debt, output gap, inflation rate and interest rate in France between 1980 to 2014 by using Granger's technique. According to the study monetary policy is more usefull to stabilize economic activity than the fiscal policy.

Jawadia, Mallick \& Sousac (2016) using a Panel Vector Auto-Regressive (PVAR) model investigate the impact of fiscal and monetary policy shocks for five key emerging market economies (Brazil, Russia, India, China, and South Africa). The study showed that monetary contractions lead to a fall in real economic activity and while government spending shocks have strong Keynesian effects. It is also found that there is coordination between fiscal policy and monetary policy. 
Akıncı \& Tuncer (2018), using data for the period of 2006:Q1-2016:Q3, analyzed which policy is more effective in Turkey by ARDL bound test. According to the empirical analysis it was found that monetary policy is more effective for the related period.

Bianchi \& Melosi (2019) reviewed the implications of the lack of monetary and fiscal policy coordination in determining inflation and inflation expectations by building a Fisherian model. They found that in the cases of lack of monetary and fiscal coordination and presence of a large stock of debt, the economy may go round in circles of higher inflation, monetary tightening, output contraction, and further debt accumulation.

\section{Methodology and Findings}

The empirical analysis in this study was carried out via Vector Autoregression (VAR) and ARDL models. Annual time series of Turkey involved 2000-2018 period were used in the analyses. The variables used in the study are inflation rate, monetary policy interest rate, budget deficit/GDP ratio and public debt/GDP ratio. Annual percentage changes of CPI (end of the year inflation rate) are used to represent the inflation rate in the study. As a proxy of the monetary policy rate, the overnight borrowing interest rate was used until 2010, then CBRT average funding cost was used. These series was acquired from the CBRT electronic data distribution system. Budget deficit/GDP ratio and public debt/GDP ratio were taken from the Republic of Turkey Ministry of Finance General Directorate of Budget and Fiscal Control.

Table 1. Definition of the Variables

\begin{tabular}{c|c}
\hline Variables & Definitions \\
\hline \hline inf & Inflation \\
bdef & Budget deficit/GDP \\
pdebt & Public debt/GDP \\
intrate & Monetary Policy Interest Rate \\
\hline
\end{tabular}

Short term interest rate is accepted as the instrument of monetary policy. However, there is no consensus about what fiscal instrument should be. In this study, the CBRT policy rate is used as the instrument of monetary policy, while fiscal deficit and public debt as a fraction of GDP are defined as the instruments of fiscal policy.

VAR models allow examining the dynamic and simultaneous interactions between different variables. The VAR model, which deals with all variables in systemic integrity and examines the mutual relations between variables, is the most commonly used model in empirical analyzes on monetary policy.

A two variable VAR model can be shown as below:

$$
\begin{aligned}
& y_{t}=\propto_{1}+\sum_{i=1}^{q} b_{1 i} y_{t-i}+\sum_{i=1}^{q} b_{2 i} x_{t-i}+\varepsilon_{1 t} \\
& x_{t}=c_{1}+\sum_{i=1}^{q} d_{1 i} y_{t-i}+\sum_{i=1}^{q} d_{2 i} x_{t-i}+\varepsilon_{2 t}
\end{aligned}
$$

q denotes the lag length, whereas $\varepsilon$ represents error terms that are uncorrelated, fixed variance, normal distribution.

The causality relationships of the variables in the VAR model are identified via the Granger causality test. However, Granger causality test does not provide information on whether this variable can be used as a proper policy instrument or not. Instead, impulse-response functions are used to determine whether a 
variable can be used as a policy instrument or not. Impulse response functions show the response of one variable to an impulse in another variable in a system that involves a number of variables as well. If one variable reacts to an impulse in another variable it can be said that the latter causal for the former.

All variables must be stationary in a VAR model. Before the analysis, Augmented Dickey-Fuller (ADF) (Dickey \& Fuller, 1981) unit root test were performed in order to determine whether the variables are stationary. The lag length in the ADF test is identified according to Akaike information criterion (AIC). Unit root test results are reported in Table 2 .

Table 2. ADF and Phillips-Perron Unit Root Test Results

\begin{tabular}{|c|c|c|c|c|c|c|c|}
\hline & \multicolumn{2}{|r|}{ Level } & \multicolumn{2}{|c|}{ First Difference } & \multicolumn{2}{|c|}{ Second Difference } & \multirow[t]{2}{*}{ Result } \\
\hline & Cons. & Cons.\&trend & Cons. & Cons.\&trend & Cons. & Cons.\&trend & \\
\hline inf & -2.18 & -1.88 & -6.33 & -9.92 & - & - & $\mathrm{I}(1)$ \\
\hline bdef & -1.43 & $-4.83^{*}$ & $-4.48^{*}$ & $-4.84 *$ & - & - & $\mathrm{I}(1)$ \\
\hline pdebt & $-3.43 * *$ & -0.94 & -1.79 & -2.90 & -4.23 & $4.08^{-}$ & $I(2)$ \\
\hline intrate & $-17.97^{*}$ & $-14.69 *$ & - & - & - & - & $\mathrm{I}(0)$ \\
\hline
\end{tabular}

Note: $\left({ }^{*}\right),\left({ }^{* *}\right)$ represents $1 \%$ and $\% 5$ statistical significance level respectively.

According to test results, only the monetary policy interest rate (intrate) is stationary at level. Inflation and budget deficit/GDP and public debt/GDP series are non-stationary at the level. Stationary is reached after the first difference in inflation and budget deficit/GDP series. Whereas the public debt/GDP series is stationary after the second difference.

Vector autoregressive regression estimates were obtained after unit root tests. Before the estimation of a VAR model, the most appropriate lag length of the model should be determined. LR, FPE, AIC, SIC and $\mathrm{HQ}$ criteria were used to determine the appropriate lag length. The values obtained according to these criteria are presented in Table 3. In addition, bold type values indicate the appropriate lag length for the corresponding criterion. Accordingly, the 2 lag supported by the LR, FPE, AIC and HQ criteria were determined as the appropriate lag length for the VAR model. Hereafter, the VAR model estimated using 2 lag. The model has been checked for stability conditions. Because of the fact that all inverse roots are located inside the unit circle, it is decided that the VAR process is stable.

Table 3. Appropriate Lag Length for the VAR Model

\begin{tabular}{ccccccc}
\hline Lag & LogL & LR & FPE & AIC & SC & HQ \\
\hline \hline 0 & -137.6988 & NA & 7274.690 & 20.24269 & 20.42528 & 20.22579 \\
1 & -93.83181 & 56.40046 & 154.7627 & 16.26169 & 17.17463 & 16.17718 \\
2 & -56.57158 & $\mathbf{2 6 . 6 1 4 4 5}$ & $\mathbf{1 7 . 0 1 9 7 0}$ & $\mathbf{1 3 . 2 2 4 5 1}$ & $\mathbf{1 4 . 8 6 7 8 0}$ & $\mathbf{1 3 . 0 7 2 3 9}$
\end{tabular}

The causality analysis analyzes whether the lags of a variable can be used to explain another variable. To analyze the causality relations between variables, pairwise Granger causality tests were conducted (see the results in Table 4). 
Table 4. Granger Causality Test Results

\begin{tabular}{l|l|l}
\hline Null Hypothesis & F-Statistic & P-value \\
\hline \hline bdef does not Granger Cause inf & 0.054557 & 0.9731 \\
inf does not Granger Cause bdef & $33.57171^{*}$ & 0.0000 \\
\hline bdef does not Granger Cause intrate & 0.372423 & 0.8301 \\
intrate does not Granger Cause bdef & $21.78453^{*}$ & 0.0000 \\
\hline pdebt does not Granger Cause inf & 3.332878 & 0.1889 \\
inf does not Granger Cause pdebt & 14.96626 & 0.0006 \\
\hline pdebt does not Granger Cause intrate & 3.981763 & 0.1366 \\
intrate does not Granger Cause pdebt & $25.76208^{*}$ & 0.0000 \\
\hline
\end{tabular}

$(*)$ Indicates significance at \%1 level and $\left({ }^{* *}\right)$ indicates significance at $\% 5$ level.

Test results show that inflation (inf) and monetary policy interest rate (intrate), Granger causes both budget deficit/GDP (bdef) and public debt/GDP (pdebt) at \%1 significance level. These results show that changes in inflation and monetary policy interest rates precede the variations in the budget deficit and public debt. On the other hand, according to the acquired results, no meaningful causality relationship was found from budget deficit/GDP (bdef) and public debt/GDP (pdebt) to inflation (inf) and monetary policy interest (intrate). The impact response graphs confirm these findings.

Figure 1. The Reaction of Fiscal Policy to Monetary Shocks

1.a. Response of Budged Deficit to Monetary Shocks

Inflation

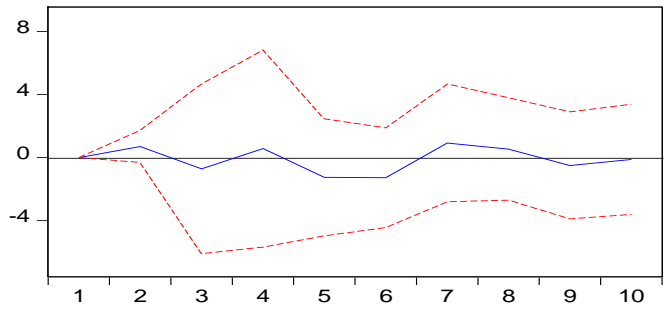

Monetary Policy Interest Rate

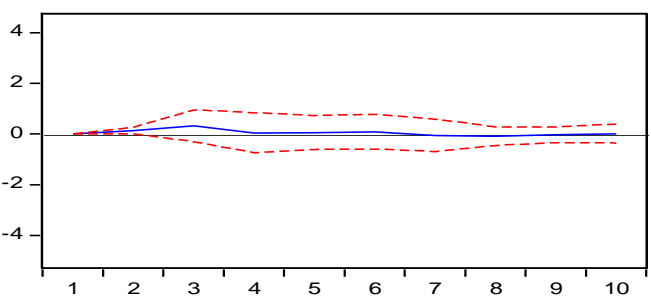

Monetary Policy Interest Rate

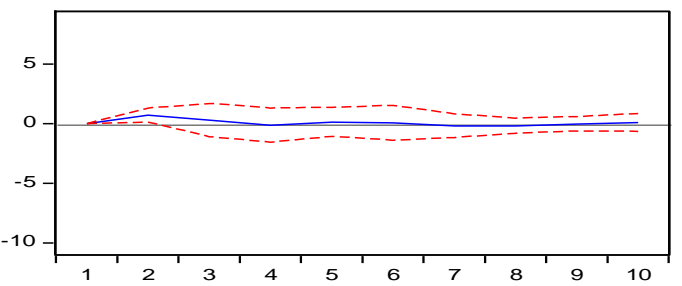

In the predicted VAR model, the impulse - response functions obtained as a result of one unit positive shock given to the variables are presented in Figure 1 and Figure 2 below. Figure 1 presents the impulseresponse function depicted reaction of fiscal policy variable to as regards to shocks in monetary policy variables. The effect of a shock on inflation rate on the budget deficit / GDP ratio is positive and significant (First graph in 1.a). Budget deficit rises temporarily in response to an inflation shock. In the second period, although the effect is still positive, it starts to decrease and then gradually returns to its trend. The second 
graph in 1.a shows the reaction of budget deficit to shocks of the monetary policy rate. The effect of a shock on the policy rate on the budget deficit / GDP ratio is positive and significant. However, the impact of a monetary policy rate is both smaller and less persistent than the impact of an inflation shock. The reaction of the budget deficit to policy rate seems to limited.

The reaction of public debt/GDP rate to shocks on inflation is seen in the graph 1.b. The reaction of public debt to monetary variables is very similar to the reaction of the budget deficit. The effect of a shock on inflation rate on the public debt / GDP ratio is positive and significant. The effect grows, reaching a peak effect on public debt around fourth quarters after the shock. The fall from the peak point is quite fast. The effect of a shock on policy rate on the public debt/ GDP ratio is positive and significant. However, the reaction of the budget deficit to policy rate seems limited similar to budget deficits. The effect peaks around the second period then falls.

Figure 2. The reaction of Monetary Policy to Fiscal Shocks

\section{2a. Response of Inflation to Fiscal Shocks}

Budged Deficit

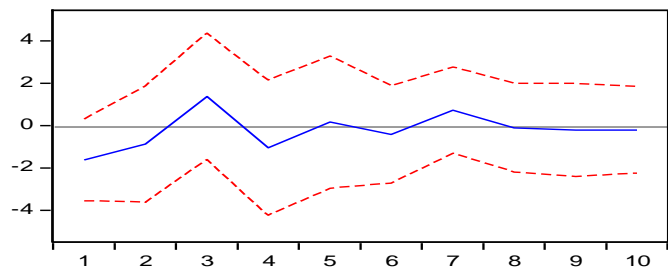

Public Debt

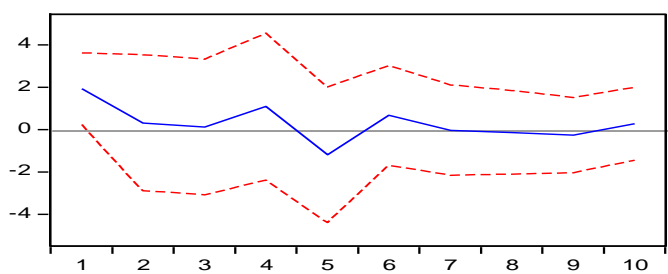

2b. Response of Monetary Policy Interest Rates to Fiscal Shocks Budged Deficit

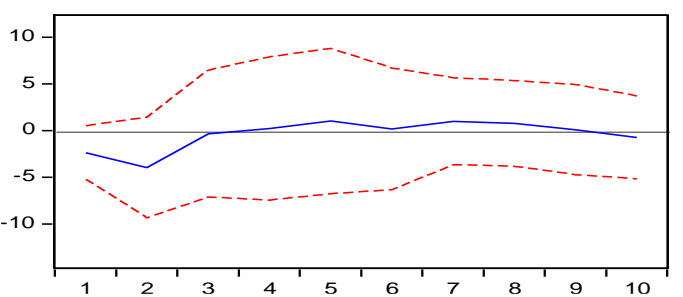

Public Debt

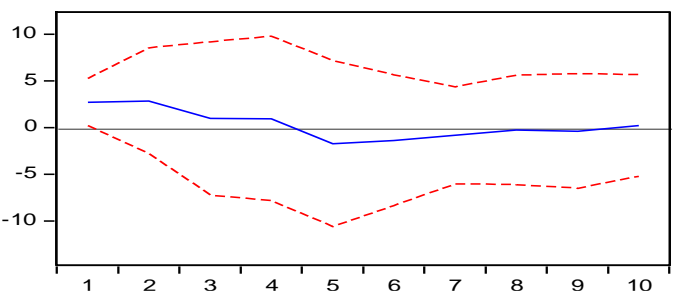

Inflation and monetary policy interest rates may be affected by fiscal policy shocks. Figure 2 presents the response of monetary policy variables to shocks in fiscal policy variables. Figure in 2a presents the reaction of inflation to shocks in the budget deficit and public debt. According to the figure, inflation gives a statistically unsignificant response to a shock on the budget deficit and public debt. Likewise, the monetary policy interest rate shows an unsignificant reaction to shocks on the budget deficit and public debt (Figure 2b).

Both causality test results and impulse-response analysis indicate that monetary policy dominates fiscal policy in the relevant period. According to these results, monetary dominance prevails in the relevant period and fiscal policy is influenced by monetary policy significantly.

After the causality tests and impact-response analyzes, the short and long term effects of monetary variables on fiscal variables were investigated by ARDL bound test. Whether economic variables act together in the long term can be determined by cointegration tests. However, in most cointegration tests, the variables should be I (1). ARDL bound test developed by Paseran et al. (2001) is a cointegration test that can be applied regardless of whether all of the variables are only I (0), only I (1) or mutually co-operative. In the ARDL bound test, the cointegration relationship between variables that is stationary at different degrees can be investigated. 
Since the ARDL bound test allows the variables to be stationary at most I(1), the budget deficit / GDP ratio was used as the independent variable to represent the fiscal policy. Unrestricted Error Correction Model (UECM) is shown in equation (3)

$$
\Delta \text { bdef }=\beta_{0}+\sum_{i=1}^{k} \beta_{1 i} \Delta \operatorname{sinf}_{t-i}+\sum_{i=0}^{p} \delta_{i} \text { intrate }_{t-i}++\gamma_{i} \text { inf }_{t-1}+\varepsilon_{i} \text { intrate }_{t-1}+u_{t}
$$

Table 5. F-statistic and Critical Values for Boundary Test

\begin{tabular}{|c|c|c|}
\hline $\begin{array}{l}\text { Model } \\
\text { F Statistic } \\
\text { k }\end{array}$ & \multicolumn{2}{|l|}{ ARDL $(1,1,0)$} \\
\hline Critical Values & Lower Boundary & Upper Boundary \\
\hline$\% 1$ & 6.34 & 7.52 \\
$\% 5$ & 4.87 & 5.85 \\
$\% 10$ & 4.19 & 5.06 \\
\hline
\end{tabular}

Note: Optimal lag length is decided according to the Akaike information criterion. $\left(^{*}\right)$ indicates $1 \%$ statistical significance level. $k$ is the number of independent variables. Critical boundary values were obtained from Pesaran et al.(2001: 301), Table Cl (v) Case V (Unrestricted intercept and unrestricted trend).

As shown in Table 5, the F statistic (10.77) calculated for $\operatorname{ARDL}(1,1,0)$ is greater than the upper boundary value (7.52) at $1 \%$ significance level. Accordingly, HO hypothesis is rejected and it is decided that there is a cointegration relationship amongst the variables. Table 6 shows the diagnostic test statistics for the ARDL model. It is seen that there is no autocorrelation, model building error and heteroscedasticity problems in the model.

Tablo 6. Diagnostic Tests for the ARDL Model

\begin{tabular}{|l|l|}
\hline Model & ARDL $(1,1,0)$ \\
Adjusted R2 & 0.92 \\
F Statistic & $28.62(0.00)$ \\
Breusch-Godfrey LM Test & $0.68(0.52)$ \\
Ramsey Reset & $0.30(0.74)$ \\
ARCH Test & $0.55(0.46)$ \\
Jarque-Bera & $3.91(0.14)$ \\
\hline
\end{tabular}

Note: Values in parentheses are probability values. $\left(^{*}\right)$ indicates $1 \%$ statistical significance level.

Assuming that the results presented in Table 5 and Table 6 reveal the necessary findings for the existence of a long-term relationship amongst to the variables, the ARDL model has been established and the long-term coefficients have been calculated to examine the long-term relationships.

$$
b d e f_{t}=\beta_{0}+\sum_{i=0}^{k} \beta_{1 i} \text { inf }_{t-i}+\sum_{i=0}^{p} \delta_{i} \text { intrate }_{t-i}+u_{t}
$$

The long-term coefficients, $t$ statistics and probability values calculated using the estimated ARDL $(1$, $1,0)$ model are presented in Table 7. In Table 7, it is seen that the coefficient of inflation variable is positive and statistically significant at $1 \%$. The monetary policy interest rate coefficient is negative and statistically significant at $5 \%$. 
Tablo 7. Long-Term Coefficients

\begin{tabular}{cccc}
\hline \multicolumn{4}{c}{ ARDL $(\mathbf{1}, \mathbf{1}, \mathbf{0})$} \\
\hline \hline Variables & Coefficient & t Statistic & Prob. \\
\hline inf & 0.43 & $6.84^{*}$ & 0.00 \\
intrate & -0.22 & $-2.91^{* *}$ & 0.01 \\
\hline Note: $\left({ }^{*}\right)$ and $\left({ }^{* *}\right)$ show $1 \%$ and $5 \%$ significance level respectively.
\end{tabular}

In the ARDL model, the short-term dynamic relations of the variables that have a cointegration relationship are examined with the Error Correction Model (ECM). In the error correction model, the shortterm deviation of the co-integrated variables from the long-term equilibrium is caught by the error correction term $\left(e c_{t-1}\right)$. The error correction model adapted to the study is shown in equation (5).

$$
\Delta b d e f_{t}=\beta_{0}+\gamma_{i} e c_{t-1}+\sum_{i=1}^{k} \beta_{1 i} \Delta i n f_{t-i}+\sum_{i=0}^{p} \delta_{i} \text { intrate }_{t-i}+u_{t}
$$

Table 8 presents the results of the error correction model. In Table 8, the error correction term appears to be negative and significant [ec $(-1)=-0.74]$. Accordingly, the long-term equilibrium will be reached again in case of deviation. The coefficient of the inflation variable ( $\Delta$ inf) obtained from the error correction model is positive and statistically significant at $1 \%$ level similar to the long-term results.

Tablo 8. Error Correction Model

\begin{tabular}{lccc}
\hline Variable & Coefficient & t-Statistic & Prob. \\
\hline \hline ec(-1) & $-0.740053^{*}$ & -6.141426 & 0.0001 \\
$\mathrm{C}$ & $1.623281^{* *}$ & 2.531180 & 0.0264 \\
$\Delta$ inf & $0.184402^{*}$ & 6.282547 & 0.0000 \\
trend & $-0.117983^{* * *}$ & -2.139113 & 0.0537 \\
Diagnostic Tests & Statistics & & \\
\hline \hline $\mathrm{R}^{2}$ & 0.76 & & \\
Adj. $\mathrm{R}^{2}$ & 0.72 & & \\
F Stat. & $15.62(0.00)^{*}$ & & \\
\hline
\end{tabular}

Note: $\left({ }^{*}\right),\left({ }^{* *}\right)$ and $\left({ }^{* * *}\right)$ show $1 \%, 5 \%$ and $\% 10$ significance level respectively.

Figure 3. Cusum and CusumSQ Tests

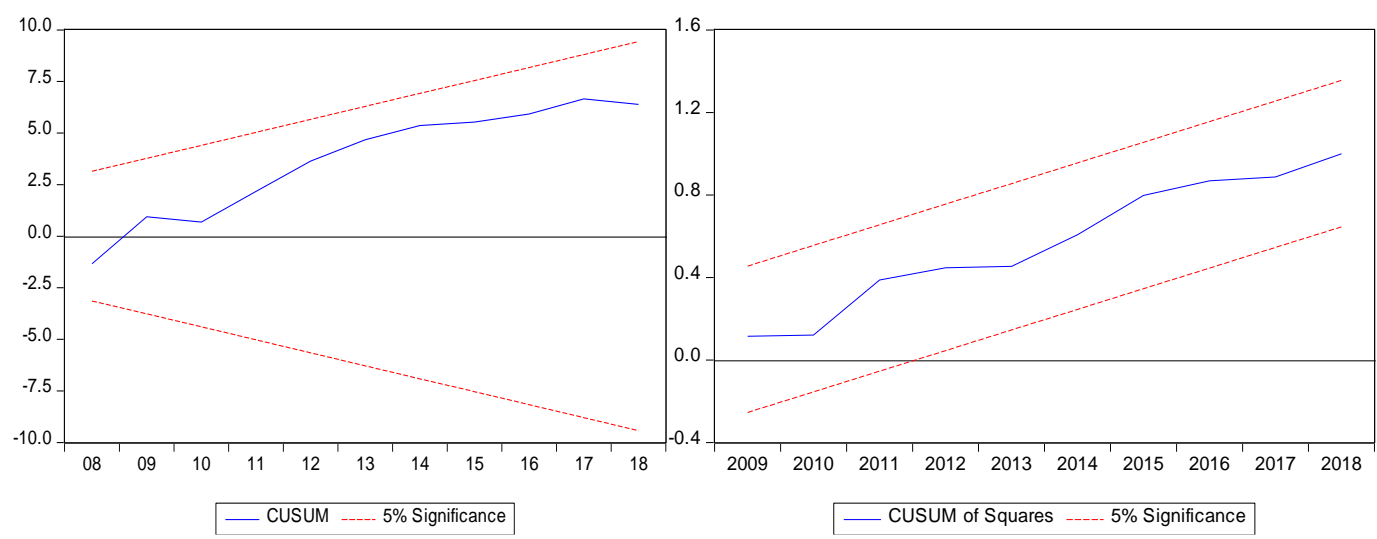


Cusum and CusumSQ test graphs performed to analyze the stability of ARDL models and to investigate structural breaks in the variables are presented in Figure 3. When Figure 3 is examined, it is seen that the Cusum and CusumSQ statistics are between critical values at $5 \%$ significance level. Accordingly, calculated parameters are stable and there is no structural break in the model.

\section{Conclusion}

Monetary and fiscal policies are that could not be completely independent of each other in terms of their effect. Fiscal authority's public debt management and size of fiscal deficit may affect inflation and interest rates even endanger the independence of the central bank. On the other side, the monetary authority's action also may affect the financing cost of the budget deficit by changing interest rates and eventually, the size of the public debt itself.

In the case of fiscal indiscipline, it is difficult for the central bank to maintain a tight monetary policy to fight inflation. The high fiscal deficit and the public sector indebtedness increase the risk premium, raising interest rates and thus necessitating the borrowing from central bank resources, leading to inflation. This is called unpleasant monetary arithmetic, as mentioned before. Even if the central bank is initially determined to tackle inflation, it will eventually have to abandon its tight monetary policy. If financial dominance prevails, the independence of monetary policy is out of the question. In other words, if fiscal policy is indisciplined, implementing a disciplined monetary policy becomes extremely difficult.

In this study, using data of Turkish economy for the 2000-2018 period, the relationship between monetary policy and fiscal policy have been examined using the VAR and ARDL method and tried to determine the level of monetary and fiscal dominance for the relevant period. According to both causality tests and impulse response analyzes, it is understood that fiscal variables have no significant effect on monetary variables in the related period. On the other hand, monetary variables are an important determinant of fiscal variables. According to these findings, it is understood that monetary policy dominates fiscal policy.

As the results of the tests showed that the budget deficit and public debt did not affect inflation and interest rates, it indicates that there was no unpleasant monetary arithmetic problem in the period under consideration. This implies that the tight monetary policy stance maintained by the central bank in the fight against inflation is not hindered by the fiscal policy. On the other hand, the fact that the public borrowing requirement was at the lowest levels in the same period limited the negative impact of the CBRT's tight monetary policy on the budget balance. These findings are consistent with results of studies addressed Turkey in the literature section.

When the results are evaluated, it is understood that monetary and fiscal policies do not affect each other negatively. Of course, this result is attributable to the achievement of fiscal discipline at the related period in which the budget deficit and public indebtedness rates are below the European Union standards. Therefore, there should be no compromise on fiscal discipline. Otherwise, it is inevitable that possible interest rate hikes in the anti-inflation environment will lead to further deterioration of the fiscal balance, resulting in unpleasant monetary arithmetic.

\section{End Notes}

1. A draft version of this paper was presented at ICOAEF'19, V. International Conference on Applied Economics and Finance at Kyrenia - North Cyprus. 


\section{References}

Ahmad, M. J., Sheikh, M. R., \& Tariq, K. (2012). Domestic debt and inflationary effects: An evidence from Pakistan. International Journal of Humanities and Social Science, 2(18), 256-263.

Akıncı, A., \& Tuncer, G. (2018). Effectiveness of fiscal policy and monetary policy in Turkey. Dumlupınar Üniversitesi Sosyal Bilimler Dergisi, 1(57), 120-128.

Aktaş, Z., Kaya, N., \& Özlale, Ü. (2010). Coordination between monetary policy and fiscal policy for an inflation targeting emerging market. Journal of International Money and Finance, 29, 123-138.

Alesina, A., \& Summers, L. H. (1993). Central bank independence and macroeconomic performance: Some comparative evidence. Journal of Money, Credit and Banking, 25(2), 151-162.

Bianchi, F., \& Melosi, L. (2019). The dire effects of the lack of monetary and fiscal coordination. Journal of Monetary Economics, 104, 1-22.

Barro, R. J. (1974). Are government bonds net wealth? Journal of political economy, 82(6), 1095-1117.

Blinder, A. S. (1982). Issues in the coordination of monetary and fiscal policy. Nber Working Paper Series, Working Paper No. 982.

Canzoneri, M. B., Cumby, R. E., \& Diba, B. (2002). Should the European Central Bank and the Federal Reserve be concerned about fiscal policy? Federal Reserve Bank of Kansas City's Symposium on "Rethinking Stabilization Policy" at Jackson Hole, August $29-31$.

Daly, H. (2015). Coordination of monetary and fiscal policies in France: An empirical overview. International Journal of Economics, Commerce and Management, 3(1), 1-20.

Dickey, D. A., \& Fuller, W.A. (1981). Distribution of the estimators for autoregressive time series with a unit root. Econometrica, 49, 1057-1072.

Ekpo, A. H., \& Omoruyi, S. (2013). Fiscal policy coordination: Issues with illustration from Nigeria. West African Financial and Economic Review, 10(1), 1-29.

Hanif, M. N., \& Arby, M. F. (2003) Monetary and fiscal policy coordination. Munich Personal Repec Archive, No: 10307.

Jawadi, F., Mallick, S. K., \& Sousa, R. M. (2016). Fiscal and monetary policies in the BRICS: A panel VAR approach. Economic Modelling, 58, 535-542.

Lambertini, L., \& Rovelli, R. (2002). Independent or coordinated? Monetary and fiscal policy in EMU. Monetary policy, fiscal policies and labour markets. Macroeconomic policymaking in the EMU. https://pdfs.semanticscholar.org/d447/a665fc0b658baf5664cc456f54375eca57d1.pdf (21.04.2019).

Laurens, B., \& De La Piedra, E. (1998). Coordination of monetary and fiscal policies. IMF Working Paper, No. 98/25, https://papers.ssrn.com/sol3/papers.cfm?abstract_id=882258 (12.04.2019).

Nordhaus, W. D. (1994). Policy games: Co-ordination and independence in monetary and fiscal policeis. Brookings Papers on Economic Activity, 2, 139-216.

Özatay, F. (2015). Parasal iktisat: kuram ve politika (4. Baskı). Ankara: Efil Yayınevi

Pesaran, M. H., Shin, Y., \& Smith, R. J. (2001). Bounds testing approaches to the analysis of level relationships. Journal of Applied Econometrics, 16(3), 289-326.

Sargent, T. J., \& Wallace, N. (1981). Some unpleasant monetarist arithmetic. Quarterly Review, FRB of Minneapolis, 5(3), 1-17.

Woodford, M. (1995). Price level determinacy without control of a monetary aggregate. National Bureau of Economic Research, Working Paper No. 5204. 
This Page Intentionally Left Blank 